\title{
JUURNAL.RU
}

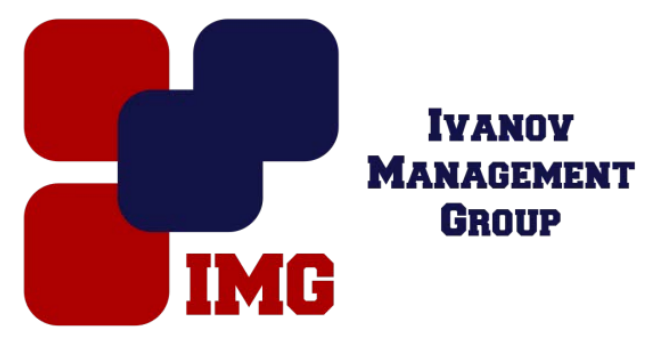

Маминова Н.В., Иванова И.С. Владимирский государственный университет имени Александра Григорьевича и Николая Григорьевича Столетовых Владимир, Россия

doi: 10.18411/lj-30-04-2017-2-03

idsp 000001:lj-30-04-2017-2-03

\section{Активные методы обучения как основа создания постреволюционной школы}

\begin{abstract}
Аннотация
Статья посвящена истории внедрения активных методов обучения в отечественное школьное образование, их влиянию на строительство новой трудовой школы после 1917 г., раскрыто их использование передовыми отечественными педагогами, философами, исследователями, политическими деятелями в создании новой школьной системы.

Ключевые слова: активные методы обучения, трудовая школа, постреволюционный период.

Одной из основных задач современной школы является формирование личности с активной гражданской позицией, умеющей доказывать свою точку зрения, активно и конструктивно участвовать в жизни общества. В связи с этим возрастает роль активных методов обучения, способствующих формированию коммуникативных навыков, умения отстаивать свою позицию, развивающих критическое мышление.

Активные методы обучения - это система методов, обеспечивающих активность мыслительной и практической деятельности учащихся в процессе усвоения учебного материала.

В истории отечественного образования имеется конструктивный опыт использования активных методов обучения для создания новой школы, обращение к которому может быть полезным в связи со стремлением к
\end{abstract}


демократизации и развивающему образованию как на постреволюционном, так и на современном этапах развития.

После революции 1917 г. в связи с изменением экономических отношений и переоценкой культурных ценностей возникла необходимость строительства новой школы. Школа стала местом, куда ребёнок приходит не только в определенные часы, она взяла на себя задачу организации почти всего времени ребёнка, то есть не только его труда, но и отдыха.

Стоит отметить, что «Декларация о единой трудовой школе» 1918 г. и программы ГУСа опирались фактически на педагогические идеи педагогики американского прогрессивизма, лидером которой был Джон Дьюи. Школа у Дьюи - это, прежде всего, миниатюрная модель общественных отношений, школа-община, где ученики играют свои социальные роли, где уважаются права и свободы каждого отдельного ученика.

Многие отечественные педагоги, философы, исследователи, политические деятели начали повсеместно внедрять активные методы в новую школу.

А.В. Луначарский, первый народный комиссар просвещения РСФСР считал, что что изучаемый материал должен восприниматься не путем книжной учебы, а путем наглядным и активным, путем прогулок, экскурсий в процессе лабораторных занятий, зарисовки, лепки, моделирования и т.п., путем активной разработки некоторых тем с самостоятельным привлечением материала, групповой разработки в дискуссиях путем коллективных сводок и т.д. Он внедрял в учебную практику активные методы и приемы преподавания (экскурсии, лабораторные занятия, моделирование и т.п.). Обучение предполагало приобщение детей и подростков к общественно-полезному труду (формирование навыков в игре, знакомство с его видами в школьных мастерских и на фабриках).

Н.К. Крупская, являясь с 1917 г. заместителем наркома просвещения, ратовала за внедрение таких активных методов в обучение, как экскурсии, трудовой метод, метод проектов. Она заверяла, что только благодаря активным методам обучения можно построить новую школу, радикально отличающуюся от старой с её военной дисциплиной, подавлением личности и механической зубрёжкой.

В.Н. Шульгин, директор Института методов школьной работы (19221931),уделил огромное внимание интерпретации метода проектов в местных условиях. Он пытался ввести школьников в круг хозяйственных иобщественных 
проблем, которые стремилось решать государство, при помощи метода проектов.

А.П. Пинкевич, активно участвовавший в создании советской системы народного образования, писал: «Движение - вот что прежде всего характеризует новую школу, школу активную. Учащийся действует, самостоятельно решает различные задачи, причем он не только напрягает свой мозг, но пускает в ход свои мускулы... Он не прикован к столу или парте, он свободен в своих движениях; он не вынужден быть молчаливым и тихим, он может говорить, может советоваться с товарищами, помогать им или просить их о помощи и т.Д.».

А.Г. Калашников в 1919-1925 гг. разрабатывал пути создания индустриально-трудовой школы и выделял следующие ее особенности: связь с жизнью, активный метод, внутренний строй и самоуправление учащихся.

Отечественный педагог С.Т. Шацкий, организатор общества «Сеттлемент» (позднее «Детский труд и отдых»), детской трудовой колонии «Бодрая жизнь», руководитель Первой опытной станции по народному образованию НКП РСФСР, ведущими принципами во всех начинаниях ставил прочную связь обучения с жизнью, с окружающей средой, тесное взаимодействие теории и практики. Он пытался осилить активные методы, связанные с интересами детей и возможным развитием их способностей, проверял теоретические идеи через их практическое применение.

П.П. Блонский сыграл важную роль в развитии отечественного образования. Он также отстаивал идею трудовой политехнической школы, идею объединения обучения с производительным трудом. В его книге «Трудовая школа» (1919 г.) школа выступает как единая индустриально-трудовая школа, представляющая собой детскую культурную жизнь, создаваемую детьми при участии взрослых.

M.M. Рубинштейн, преподаватель психологии и философии, автор трудов по философии, истории педагогики и психологии, анализируя механизмы стимуляции познавательной деятельности учащихся, уделял достаточно большое внимание в своих работах методу проектов. Он считал, что в пробуждении интереса ученика играют роль глубинные психологические явления, связанные с актуальными потребностями, и считал интерес ученика «...истинным двигателем новой школы».

Отечественный исследователь Б.Б. Комаровскийразвивал идею о демократизации школы и личности, связи обучения с жизнью и 
производительным трудом, соединении духовного развития личности с развитием способностей к общественной работе.

Таким образом, использование активных методов обучения сильно облегчило задачу строительства новой школы в постреволюционный период. На переломном этапе в развитии школы и общества активные методы стали основой процесса обучения, незаменимыми в выполнении общественно важной задачи формирования личностинового типа. Обращение к имеющемуся положительному опыту использования активных методов обучения может оказаться полезным для модернизации современного российского образования.

\section{Литература}

1. Герций, В.И. Использование активных методов обучения, стимулирующих познавательную деятельность учащихся, на уроках истории [Электронный ресурс] / URL: http://nsportal.ru/shkola/istoriya/library/2014/04/30/aktivnye-metodyobucheniya(дата обращения: 07.04.2017).

2. Крупская, Н.К. Метод проектов в политпросветработе [Текст] / Н.К. Крупская // Коммунистическое просвещение. - 1923. - 3(9). - С. 25-31.

3. Луначарский, А.В. Какая школа нужна пролетарскому государству [Текст] / А.В. Луначарский // О воспитании и образовании. - М., 1976. - С. 100.

4. Маркарьян, Т.Г. Школа, ребёнок и учитель [Текст] / Т.Г. Маркарьян. - Ростов на Дону-Краснодар: Буревестник, 1924. - С. 16.

5. Пинкевич, А.П. Педагогика. Трудовая школа. Часть 2 [Текст] / А.П. Пинкевич. - М.: Работник Просвещения, 1925. - 559 с.

6. Пинкевич, А.П. Педагогика [Текст] / А.П. Пинкевич. Т.1. - М.: Работник Просвещения, 1924. - С. 32, 114.

7. Рубинштейн, М.М. Основы трудовой школы [Текст] / М.М. Рубинштейн. Иркутск, 1920. - 28 с.

8. Советская производственно-трудовая школа: Педагогическая хрестоматия [Текст]; под ред. А.Г. Калашникова; сост. В. Вейкшан и С. Риверс. Т. 1, изд.3-е. - М.: Работник просвещения, 1925. - 174 с.

9. Шацкий, С.Т. Педагогические сочинения: В 4-х т. Т. 1 [Текст] / С.Т. Шацкий; под ред. И.А. Каирова, Л.Н. Скаткина, М.Н. Скаткина, В.Н. Шацкой. - М.: Изд-во Академии педагогических наук РСФСР, 1962. - 502 с.

10. Эпштейн, М.М. Метод, разрушающий школьную рутину. О жизни замечательной идеи Дж. Дьюи в отечественной и зарубежной педагогике [Текст] / М.М. Эпштейн // Школьные технологии. - 2009. - № 2. - С. 41-44. 